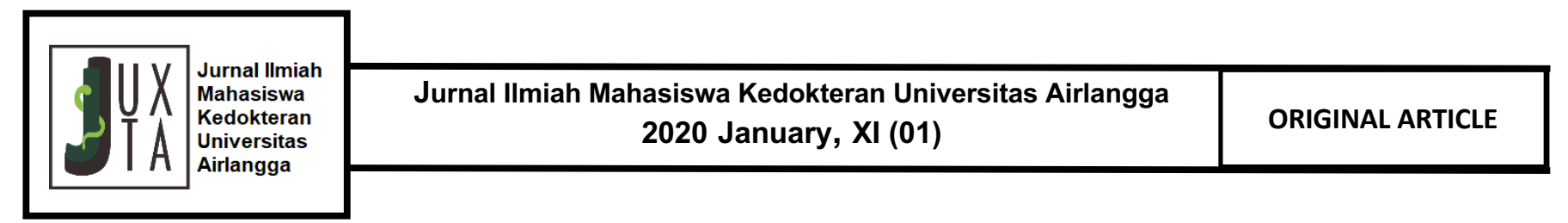

\title{
Effectivity of Cacao Rind Ethanol Extract in Inhibiting Streptococcus Pyogenes Growth In Vitro
}

\author{
Cynthia Dwi Ramadhanie ${ }^{1}$, Sri Purwaningsih ${ }^{2^{*}}$, Eko Budi Koendhori ${ }^{3}$
}

\begin{abstract}
${ }^{1}$ Faculty of Medicine, Universitas Airlangga, Surabaya, Indonesia.
${ }^{2}$ Department of Medical Pharmacology, Faculty of Medicine, Universitas Airlangga, Surabaya, Indonesia.

3 Department of Medical Microbiology, Faculty of Medicine, Universitas Airlangga, Surabaya, Indonesia.
\end{abstract}

\section{A B S T R A C T}

Introduction: Infectious disease is still a common cause of illness and death in developing countries, such as Indonesia. One of the bacteria that causes infectious disease is Streptococcus pyogenes. Cacao fruit is a large commodity in Indonesia and has benefit for human. Cacao's rind is known to contain several active compounds such as flavonoid and alkaloid that have antibacterial effect that can inhibit Streptococcus pyogenes growth. This research aims to evaluate the Minimum Bactericidal Concentration (MBC) of cacao rind ethanol extract in inhibiting Streptococcus pyogenes growth in vitro.

Methods: This research was a laboratory experimental study, testing antibacterial activity of cacao's rind ethanol extract in inhibiting growth of bacteria Streptococcus pyogenes using dilution method in vitro to know the MIC and MBC result. Sample of bacteria Streptococcus pyogenes was obtained from Balai Besar Laboratorium, Surabaya. Sample of cacao's rind ethanol extract was extracted at Balai Materia Medica, Batu.

Results: At the beginning this experiment was done to find the MIC and MBC of cacao's rind ethanol extract against the growth of bacteria Streptococcus pyogenes, but the researcher can only find the MBC result, because the extract color is very dark, so the turbidity result of tubes P1 - P7 cannot be compared to control tube. From the results, the researcher draws a table showing how turbid and dark those tubes are. More $(+)$ signs means more turbid or darker the tube is. From dilution test, the MBC of cacao's rind ethanol extract against the growth of bacteria Streptococcus pyogenes is $12.5 \%$.

Conclusion: Cacao's rind (Theobroma cacao L.) was quite effective in increasing the growth of bacteria Streptococcus pyogenes in vitro, the Minimum Bactericidal Concentration (MBC) is $12.5 \%$

*Correspondence: sri-p@fk.unair.ac.id

JUXTA: Jurnal IImiah Mahasiswa Kedokteran Universitas Airlangga

p-ISSN: 1907-3623; e-ISSN: 2684-9453

DOI: $10.20473 /$ juxta.V11/12020.6-8

Open access under Creative Commons Attribution-ShareAlike 4.0 International License (CC-BY-SA) C) () (2)

\section{ARTICLE INFO}

Article history:

Received 04 December 2019

Received in revised form 17 January 2020

Accepted 23 January 2020

\section{Keywords:}

Streptococcus pyogenes, Theobroma cacao L., Ethanol extract,

Antimicrobial,

Dilution test. 


\section{Introduction}

Infectious disease is still a common cause of illness and death in developing countries, such as Indonesia. Infectious disease gives enormous impacts on the patients, such as physical suffering, lower working capability, and productivity that will lead to material loss. ${ }^{1}$

One of the bacteria that causes infectious disease is Streptococcus pyogenes, an extracellular gram positive bacteria that colonize the throat or skin which are highly potential in causing suppurative and non suppurative infections. The most common infections caused by Streptococcus pyogenes are pharyngitis, scarlet fever, and impetigo. Streptococcus has been an epidemic for the last ten years with $\mathrm{M} 1$ stereotype as predominant. $^{2}$

Group A Streptococcus has developed and become resistant to clindamycin and macrolides antibiotic, such as erythromycin, azithromycin, and clarithromycin. Group A Streptococcus also becomes resistant to tetracycline. ${ }^{3}$

Cacao crop (Theobroma cacao L.) is a large commodity in Indonesia. Cacao fruit consist of three parts, $74 \%$ rough rind, $24 \%$ seed, and $2 \%$ fruit placenta. The most widely used part from cacao fruit is its bean or seed, cacao bean is one of the largest export commodity so the other parts of cacao plants go to waste and become an environmental problem. From the data above, it is known that cacao's rind is the largest waste from cacao plant. In 2007 , the number of cacao's rind waste was 508.84 tons and 545.88 tons in $2008 .^{4,5}$

Cacao's rind is known to contain several active compounds such as flavonoid and alkaloid that have antibacterial effect. Cacao's rind also contain 3 importants polyphenols that have antioxidant effect, such as proantocyanidine, catechin, and antocyanidinie. ${ }^{6,7}$

Previous experiment showed that the type of cacao's rind extract named Lindak may inhibit growth of Staphylococcus aureus, Streptococcus mutan, Eschericia coli, and Salmonella thypii bacteria. ${ }^{8}$

\section{Methods}

This study was a laboratory experimental study, testing antibacterial activity of cacao's rind ethanol extract in inhibiting growth of bacteria Streptococcus pyogenes using dilution method in vitro to know the MIC and MBC result. Sample of bacteria Streptococcus pyogenes was obtained from Balai Besar Laboratorium, Surabaya. Sample of cacao's rind ethanol extract was extracted at Balai Materia Medica, Batu.
Cacao's rind was first dried under the sun and then turned into powder using a blender and weighed up to 2 kilograms. Then, maceration technique was used, up to 10 liters of $96 \%$ ethanol solvent. This maceration was done for 2 days and then evaporated using rotatory evaporator of $50 \mathrm{rpm}$ speed for 2 days. From those process, extract of $50 \mathrm{~mL}$ was produced. (UPT Materia Medica Batu 2016)

Suspension of bacteria Streptococcus pyogenes was first prepared in Muller-Hinton Broth until the turbidity is equal to Mc Farland 0.5 or $1.5 \times 10^{8} \mathrm{CFU} / \mathrm{mL}$.

First, 9 sterile tubes were prepared, 2 for negative and positive controls (K1 \& K2) and 7 for treatments (P1 - P7). $\mathrm{K} 1$ tube as negative control was given $1 \mathrm{~mL}$ ethanol extract $100 \%$. K2 tube as positive control was given $1 \mathrm{~mL}$ broth solution and $1 \mathrm{~mL}$ of bacteria suspension. P1 tube was filled with $1 \mathrm{~mL}$ of ethanol ectract $100 \%$ and $1 \mathrm{~mL}$ bacterial suspension. P2 - P7 tubes were filled with $1 \mathrm{~mL}$ of broth. P2 was added with $1 \mathrm{~mL}$ of ethanol extract $100 \%$ and then mixed and $1 \mathrm{~mL}$ of it was taken to be moved to P3 tube. This mixture-moving steps were repeated until P7 tube. When the last tube came, remove $1 \mathrm{~mL}$ out of $\mathrm{P} 7$. From these steps, it was obtained tube P1 with $100 \%$ concentration, P2 with $50 \%$ concentration, P3 with $25 \%$ concentration, P4 with $12.5 \%$ concentration, P5 with $6.25 \%$ concentration, P6 with $3.125 \%$ concentration, and P7 with $1.56 \%$ concentration. All tubes were incubated in $37^{\circ} \mathrm{C}$ temperature for 24 hours. This procedure was replicated for four times.

\section{Results}

At the beginning this experiment was done to find the MIC and MBC of cacao's rind ethanol extract against the growth of bacteria Streptococcus pyogenes, but the researcher can only find the MBC result, because the extract color was very dark, so the turbidity result of tubes P1 - P7 cannot be compared to control tube. From the results, the researcher draws a table showing how turbid and dark the tubes were. More signs (+) means more turbid or darker the tube was.

From the dilution test, samples were taken from each tube and were planted in blood agar plate, then were incubated for 24 hours in $37^{\circ} \mathrm{C}$ temperature. MBC s used to find out how much minimum concentration is needed to kill that bacteria. The MBC of cacao's rind ethanol extract against the growth of bacteria Streptococcus pyogenes is $12.5 \%$.

Table 1. Results of dilution test

\begin{tabular}{cccccccccc}
\hline \multirow{2}{*}{ Replication } & \multicolumn{9}{c}{ Cacao's rind ethanol extract } \\
\cline { 2 - 9 } & $\mathbf{1 0 0}$ & $\mathbf{5 0} \%$ & $\mathbf{2 5} \%$ & $\mathbf{1 2 . 5} \%$ & $\mathbf{6 . 2 5} \%$ & $\mathbf{3 . 1 2 5} \%$ & $\mathbf{1 . 5 6} \%$ & $\mathbf{+}$ & - \\
\hline 1 & +++++ & ++++ & +++ & +++ & ++ & + & + & - & +++++ \\
2 & +++++ & ++++ & +++ & +++ & ++ & + & + & - & +++++ \\
3 & +++++ & ++++ & +++ & +++ & ++ & + & + & - & +++++ \\
4 & +++++ & ++++ & +++ & +++ & ++ & + & + & - & +++++ \\
\hline
\end{tabular}

Source: Research Data, Processed 

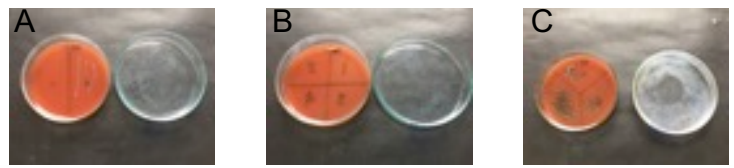

Figure 1. Planting the dilution results on blood agar plates. A. Control; B. Treatment 1-4; C. Treatment 5-7.

Table 2. Results of MBC test.

\begin{tabular}{|c|c|c|c|c|c|c|c|c|c|}
\hline \multirow[t]{2}{*}{ Replication } & \multicolumn{7}{|c|}{ Cacao's rind ethanol extract } & \multicolumn{2}{|c|}{ Control } \\
\hline & $100 \%$ & $50 \%$ & $25 \%$ & $12.5 \%$ & $6.25 \%$ & $3.125 \%$ & $1.56 \%$ & + & - \\
\hline 1 & - & - & - & - & + & + & + & + & - \\
\hline 2 & - & - & - & - & + & + & + & + & - \\
\hline 3 & - & - & - & - & + & + & + & + & - \\
\hline 4 & - & - & - & - & + & + & + & + & - \\
\hline
\end{tabular}

Source: Research Data, Processed

\section{Discussion}

The Minimum Bactericidal Concentration (MBC) is the lowest concentration of antimicrobial that can prevent growth of an organism after being subcultured on free antibiotic media. MBC of cacao's rind ethanol extract against the growth of bacteria Streptococcus pyogenes was found at $12.5 \%$. The bactericidal effect of cacao's rind ethanol extract $s$ because of its active compounds that work as antibacterial. Those active compounds are flavonoid and alkaloid. Alkaloid is an alkaline that consists of nitrogen atoms, thus it can cause protein coagulation which leads to disruption of the components of bacterial cell wall peptidoglycan. This condition causes bacterial cell wall cannot be fully formed and leads to cell death. ${ }^{6}$

Flavonoid works by inhibiting the function of bacteria's cytoplasm membrane, energy metabolism, and nucleic acid synthesis. In inhibiting nucleic acid synthesis, betaflavonoid ring creates hydrogen bond with some nucleic acid bases and then these bonds can inhibit the synthesis of bacteria's DNA and RNA. Bacteria's cytoplasm membrane function is inhibited by lowering the membrane cell wall permeability, impairing the lipid bilayer membrane, and harm barrier function and thus can cause cell death. Inhibition of energy metabolism is related to RNA, DNA, protein, and cell wall synthesis activity. ${ }^{9}$

The extraction of cacao's rind was done using ethanol $96 \%$ solvent. This concentration means that water component is only $4 \%$. Ethanol is a solvent with universal properties that can disolve polar and non-polar compounds. With such capability, it is expected that all active compounds needed can be fully extracted. The higher the purity of ethanol, the less water content, thus facilitating separation of active components from its solvent. Just like other experiment, ethanol is the best solvent for extracting tannin from Mimosa pudica plant. Rosella flower (Hibiscus sabdariffa L) $96 \%$ ethanol extract was also proven to be more active than $30 \%$ ethanol extract with greater inhibition area and smaller Minimum Bactericidal Concentration. ${ }^{10,11}$

\section{Conclusion}

Cacao's rind (Theobroma cacao L.) is quite effective in increasing the growth of bacteria Streptococcus pyogenes in vitro, the Minimum Bactericidal Concentration (MBC) is $12.5 \%$.

\section{CONFLICT OF INTEREST}

The author stated there is no conflict of interest in this study.

\section{REFERENCES}

1.Wahjono H. Peran Mikrobiologi Klinik pada Penanganan Penyakit Infeksi. Semarang: Diponegoro University, 2007.

2.Cunningham MW. Pathogenesis of Group a Streptococcal Infections. Clin Microbiol Rev. 2000; 13: 470-511.

3.Prevention CFDCA. Antibiotic Resistance Threat in the United States: (2013).

4.Indariyanti $\mathrm{N}$ and Rakhmawati. Peningkatan Kualitas Nutrisi Limbah Kulit Buah Kakao dan Daun Lamtoro Melalui Fermentasi sebagai Basis Protein Pakan Ikan Nila. Jurnal Penelitian Pertanian Terapan. 2013; 13: 108-15.

5.Murni R. Pemanfaatan Kulit Buah Kakao yang Difermentasi dengan Kapang Phanerochaete Chrysosporium sebagai Pengganti Hijauan dalam Ransum Ternak Kambing. Program Studi Peternakan Fakultas Peternakan Universitas Jambi, 2012.

6.Mulyatni A, Budiani A and Taniwiryono D. Aktivitas Antibakteri Ekstrak Kulit Buah Kakao (Theobroma Cacao L.) terhadap Escherichia Coli, Bacillus Subtilis, dan Staphylococcus Aureus. E-Journal Menara Perkebunan. 2016; 80.

7.Yulianti NFE. Aktivitas Antibakteri dan Bioautografi Fraksi Etil Asetat Ekstrak Aseton Kulit Buah Kakao (Theobroma Cacao L.) terhadap Streptococcus Mutans dan Bacillus Subtilis. 2013.

8.Sartini, Djide MN and Alam G. Ekstraksi Bioaktif dari Limbah Kulit Buah Kakao dan Pengaruhnya terhadap Aktivitas Antioksidan dan Antimikroba. Journal of Traditional Medicine. 2009; 14.

9.Lutfiani NR, Setiawatie EM and Wibisono PA. Daya Hambat Ekstrak Kulit Buah Kakao (Theobroma Cacao) terhadap Pertumbuhan Bakteri Supragingiva. Periodontic Journal. 2014; 6: 43-7.

10. Marnoto T, Haryono G, Gustinah D and Putra F. Ekstraksi Tannin sebagai Bahan Pewarna Alami dari Tanaman Putrimalu (Mimosa pudica) Menggunakan Pelarut Organik. Reaktor. 2012; 14.

11.Miranti M, Prasetyorini and Suwary C. Perbandingan Aktivitas Antibakteri Ekstrak Etanol 30\% dan 96\% Kelopak Bunga Rosella (Hibiscus sabdariffal) terhadap Bakteri Staphylococcus Aureus. Ekologia: Jurnal IImiah IImu Dasar dan Lingkungan Hidup. 2013; 13: 9-18. 
